\title{
Innovation of the Use of Education Games Method Utilizing a Thousand of Nail Media in Fiqh Lesson Madrasah Ibtidaiyah Amaliyah Pematangsiantar District
}

\author{
Amiruddin Siahaan ${ }^{1}$, Zulheddi $^{2}$, Muhammad Sidik ${ }^{3}$ \\ ${ }^{1,2,3}$ Faculty of Tarbiyah and Teacher Training, Universitas Islam Negeri Sumatera Utara, Indonesia \\ sidikmuhammad601@gmail.com
}

\begin{abstract}
This research are to determine: (1) the implementation of the innovative educational games method in Islamic Civilization History lessons, (2) the implementation of the media of a thousand nails in Islamic Civilization Studies lessons, and (3) the supporting and inhibiting factors in implementing the innovative use of the educational games method with the media of a thousand nails in the Fiqh lesson. The research method used is qualitative research, data collection is carried out in natural conditions and using data collection methods, namely: interview method, observation method, documentation method. The findings of the research show: (1) the implementation of the educational games innovation method in the Fiqh lesson is running well because it is driven by the creativity of the teacher by paying attention to the characteristics of the students, (2) the innovation of the implementation of learning using the media of a thousand nails is carried out by the teacher starting from planning, implementation to conclusions learning, and (3) the supporting factor for learning is the presence of media, namely the media of a thousand nails, while the inhibiting factor is the limited time.
\end{abstract}

Keywords

education games; a

thousand of nail media; figh lesson

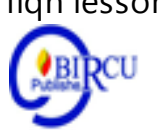

\section{Introduction}

Educators have a very big role, in addition to being facilitators in student learning, as well as guiding and directing students so that they become human beings who have broad knowledge of both religious knowledge, intelligence, life skills, skills, noble character and good personality and can build themselves to be better than before and have a big responsibility in nation building.

One of the efforts to have a responsibility to improve the quality of education is to use appropriate learning media in conveying the message. This is intended for students who have not been able to receive the message conveyed by the teacher, so the use of media is highly recommended. Thus the use of media to convey learning messages will be more appreciated without causing misunderstanding for both students and teachers.

Researchers developed a method of eduation games with the media of a thousand nails especially on the subject of Fiqh. With the education games method using the media of a thousand nails, it is hoped that students can learn fiqh with ease and fun so that their mastery of the material becomes more optimal. This is felt by students and it makes sense because the developing education games will encourage students to learn. 


\section{Review of Literatures}

Islamic education is education based on the Koran and As-sunah, always has scientific goals that have the aim of making humans as halifahs who can carry out their duties properly (Arief 2002: 29). Children are the next generation of the ideals of the nation, in the hands of the children, leadership milestones will be handed over to instill good morals, since childhood they must be introduced to religious education, basic religious education including social education, religious morality education which is usually done by studying the Koran.

Education games are games related to education (Bambang, et al 1982: 599). Playing is an activity that is carried out with or without using tools. Which produces understanding and provides information, provides pleasure and develops children's imagination (Triharso, 2013).

Several types of education games are: (1) free games in door, namely: playing pianica and tambourine music, singing, clapping, (2) outdoor physical games, namely: sports games: football, hide and seek, and gymnastics, 3) physical role playing games or role playing, and (4) Dominant non-physical games or passive play, among others: reading, playing puzzels, key towers, drawing, and coloring pictures (Ismail, 2006: 120).

Indriyani (2008: 87-89) explains that educational games have many benefits in various aspects including:

1. Physical aspects, by playing children can do activities that involve body movements that will make children healthy, the muscles of the body will grow and become strong. In addition, the limbs have the opportunity to be moved. With children's play it can also channel excessive energy, so that children will not feel restless.

2. Aspects of gross and fine motor development, this can improve children's skills.

3. Social aspects, by playing, children learn to separate from their parents or influence. Children will build relationships with peers, learn various rights, maintain relationships, use toys in turns, do joint activities, solve problems, and play social roles. By playing, children can learn to communicate with their friends. Both in terms of expressing thoughts and feelings as well as understanding what the friend said so that relationships can be built and exchange information.

4. In terms of language, playing with children will have ample opportunities to dare to speak. This is quite important for the child's ability to communicate and expand relationships.

5. Emotional and personality aspects, through playing children can release the tension they experience and children can also have an assessment of themselves about their strengths so that they can help form a positive self-concept, self-confidence and self-esteem, because children will feel competent certain.

6. Aspects of cognition, knowledge and insight of children will increase in breadth along with their reasoning power by having creativity, language skills and increasing children's memory.

7. The aspects of the acuity of the five senses, including sight, touch, smell, hearing, and taste, need to be honed in order to make children responsive and sensitive to things that are happening in the environment.

8. Aspects of the development of creativity, this activity involves the ability to see as many alternative answers as possible.

9. Therapy, play can also be used as a play activity that can change negative emotions into positive and more fun.

The thousand-nail media is a medium or intermediary that functions to transmit messages to the audience (students), in the form of various nails and boards for the bases and 
wire for the restrictions and hoses for fantasy games and learning, especially Fiqh lessons. Or more clearly, this media is a learning media in the form of a fantasy board that has many nails stuck on the board. The way to play can be in groups or individually.

The strategy of using a thousand nails learning media, with the application of a thousand nails learning media requires several steps taken by researchers in implementing learning activities, namely:

1. The time to use the game is used at the beginning of the lesson and at the end of the lesson to close the lesson to reduce student tension after several hours of study.

2. How to play, namely: (a) any game that is carried out is directed to achieve the learning objectives, (b) each game should be given clear and firm rules, (c) in team play, it is necessary to form a balanced group, (d) involving students as much as possible (the audience is given certain assignments), (e) adjusted to the level of students' abilities, f) the teacher acts as a manager and motivator to play, and (g) the game should be stopped while the students are still immersed in preoccupation (Muhaimin, 1996:90).

The advantages of using a thousand nails media are: (1) easy in learning and students immediately understand and understand, (2) practical, seen from the way it is made and used, the thousand nails media is a practical game, in using this media the teacher does not need to have special skills, This medium does not need energy and electricity. If we are going to use it, we just need to design the activity, (3) easy to remember, the characteristics of a thousand nails media are questions and answers that make it easier for children, especially in studying fiqh and easy to understand the educational material, and (4) fun, the media with a thousand nails can be used through games. In addition, in its use of this media, the game is interspersed with questions that come from the aqua glass underneath if the marble or sugar gets into the glass (Asnawir and Usman, 2002: 14).

The weaknesses of using the media of a thousand nails are: (1) sometimes the teacher forgets the learning time that the learning has been completed, (2) sometimes the child is more focused on learning and is fun to forget about the time, and (3) sometimes the child gets bored to carry out the learning if the teacher doesn't can bring this learning (Asnawir and Usman, 2002:14).

\section{Research Method}

The research method used is qualitative research, data collection is carried out in natural conditions and using data collection methods, namely: interview method, observation method, documentation method. In accordance with the main problems of this study, the types, characteristics, and sources of research carried out, the data collection chosen for further analysis in depth is the method of observation, interviews, and documentation. Sources of data in this study include primary data sources and secondary data sources. Activities in data analysis are: data reduction, data presentation, and drawing conclusions.

\section{Discussion}

The results of the research prove that innovations in the use of education games in figh lessons include (1) being able to describe objectives, (2) being able to choose material, (3) being able to analyze material, (4) being able to determine methods, (5) being able to determine learning sources / media / tool, (6) able to arrange learning tools, (7) able to make judgments, (8) able to allocate time. 
The thousand nails media used in learning is based on theory and practice. In this case the researcher directly asks the teacher in question. The theoretical basis is (1) the teacher has a scientific educational background so that he has academic and intellectual expertise (2) refers to a subject-based learning management system, (3) the teacher must have a match between scientific background and the subject that is fostered (4) the teacher has knowledge and experience in implementing learning in the classroom. In this case, a teacher must have extensive knowledge to have the knowledge that must be possessed in the teaching and learning process.

Fiqh teachers have many of the latest innovations to make interesting learning ideas. Not only a thousand nails have been made but there are also picture card media and secret box media. That is the newest idea of the fiqh teacher's innovation. Fiqh teachers never ask for any fees from schools to develop their learning media but instead use consumable materials. Consumables are usually thrown away, then the Fiqh teacher collects and assembles and joins the nails with the wire which is located on the teriplek board so that there is a thousand nails media that can be used as a learning tool.

After conducting observations, documentation, and interviews, the researchers concluded that teachers who use learning media are more attractive than teachers who are guided by one book only. In this case, Daryanto explained that media is the plural form of the word medium, which can be interpreted as an intermediary or introduction to communication from sender to receiver (Daryanto, 2011:11).

Then the researcher took the media explanation from Eko Wahyudi's thesis explaining that learning media is a device used in order to communicate the interaction between teachers and students in the learning process that is able to make students easily obtain and understand and have awareness of the importance of honesty (Wahyudi, 2016: 23).

The research findings show that the supporting factor of implementing innovation is students' interest in learning that relates the use of learning methods and media. Then the teacher is active so that students are more active in participating in the learning. Meanwhile, the inhibiting factor for the implementation of innovation is the teacher limiting the ability and time and space so that the learning that is obtained is not as optimal as possible. One of them is the facilities and infrastructure. That is the greatest obstacle to education. Therefore, researchers asked many questions directly with the teacher who made this innovation. But the teachers who made this innovation did not step back, but move forward. Making new breakthroughs how innovation is more promising in the future. It means that the teacher's job is to turn all of that into innovation and methods and tools that can be used in learning.

\section{Conclusion}

The conclusions of the study are: (1) the implementation of the educational games innovation method in Islamic Civilization History lessons went well because it was driven by the creativity of the teacher by paying attention to student characteristics by using various education games adapted to the teaching material, (2) implementing the use of a thousand nails as follows: The teacher explains to the students the use of the media of a thousand nails, the teacher takes the student's attendance, the teacher prepares the teaching material, the teacher places the media with a thousand nails on the table, the teacher divides into small groups, then the teacher calls one of the students from the group to take an envelope or queue number, the teacher gives marbles in the first group and so on to use the thousand nails media, after playing the media, a thousand marbles will enter the aqua glass containing the questions, then the group takes the question paper and answers as a group, then the group's 
answers are put into the envelope provided, the envelope $t$ This is exchanged for another group, another group reads the answer from the envelope received, then the other group provides comments, input, criticism and suggestions, and the group makes learning conclusions, and (3) the supporting factor for learning is the presence of media, namely a thousand nails, meanwhile the inhibiting factor is time limitation.

Recommendations that can be given are: (1) the education games method is often underestimated, so that teachers are lazy to implement it. And the teacher's hard work to follow the method is not to attract students but to waste time. Therefore, the head suggested that learning should use methods so that students understand the lesson more quickly, and (2) schools must be more creative in finding learning media and more creative in using the right method.

\section{References}

Ananda, Rusydi, dan Amiruddin. 2017. Inovasi Pendidikan Melejitnya Potensi Teknologi dan Inovasi Pendidkan. Medan: CV. Widya Puspita.

Ananda, Rusydi. 2018. Profesi Pendidik dan Tenaga Kependidikan (Telaah Terhadap Pendidik dan Tenaga Kependidikan). Medan: LPPPI.

Arief, Armai. 2002. Pengantar Ilmu Pendidikan Islam. Jakarta: Ciputat Press.

Asnawir dan M. Basyiruddin Usman. 2002. Media Pembelajaran. Jakarta: Ciputat Press

Bambang M, dkk. 1982. Kamus Lengkap Inggris Indonesia. Jakarta: Difa Publisher.

Deliati, Dewi, R.S., and Lesmana, G. (2019). Spirografh Media for Kindergarten Teachers of 'Aisyiyah in Tanjung Sari Village. Budapest International Research and Critics in Linguistics and Education (BirLE) Journal Vol 2 (3): 468-471.

Indriyani, Widian Nur. 2008. Panduan Praktis Mendidik Anak Cerdas Intelektual dan Emosional. Yogyakarta: Logung Pustaka.

Ismail, Andang. 2006. Education Games (Menjadi Cerdas dan Ceria dengan Permainan Edukatif). Yogyakarta: Pilar Media.

Muhaimin. 1996. Strategi Belajar Mengajar. Surabaya: Ciptra Media.

Novianti, D., Mahardika, M.S., Tuasikal, A.R. (2020). Improvement of Physical, Honesty, Discipline and Cooperation in Class IV Elementary School Students through Circuit Training Learning Model. Budapest International Research and Critics in Linguistics and Education (BirLE) Journal Vol 3 (1): 244-250.

Oe. H., Takemoto, T., and Ridwan, M. Is Gamification a Magic Tool?: Illusion, Remedy, and Future Opportunities in Enhancing Learning Outcomes during and beyond the COVID19. Budapest International Research and Critics in Linguistics and Education (BirLE) Journal Vol 3 (3): 1401-1414.

Prasasti, T.I., Solin, M., and Hadi, W. The Effectiveness of Learning Media Folklore Text of North Sumatera Based on Blended Learning by 10th Grade Students of Vocational High SchoolHarapan Mekar-1 Medan. Budapest International Research and Critics in Linguistics and Education (BirLE) Journal Vol 2 (4): 480-490.

Purnamasari, R., Simare-mare, A., and Murni, S.M. Application Analysis of Buying and Selling Game to Grow the Language Development and Attitude of Entrepreneurs on Child Age 5-6 Years in Paud RA Al-Mahir. Budapest International Research and Critics in Linguistics and Education (BirLE) Journal Vol 2, (4): 525-532.

Ririn, S.D., Perangin-angin, R.B.B., Mursid, R. (2020). Development of Multimultural PKN Interactive Learning Multimedia Development in Class IV SD IT NU Tanjung Morawa 
Academic Year 2018/2019. Budapest International Research and Critics in Linguistics and Education (BirLE) Journal Vol 3 (2): 845-853.

Siburian, S., Hutagalung, S.M., and Daulay, S. (2020). Development of Adobe Flash CS6 Learning Media in Short Story-Based on Learning Text of Advanced Local Community of Batak Toba Students in Tanjungmorawa Budapest International Research and Critics in Linguistics and Education (BirLE) Journal Vol 3 (1): 591-599.

Siregar, A.C., Adisaputera, A., and Yus, A. (2020). The Development of Interactive Media Assisted by Macromedia Flash to Improve the Ability of Understanding the Fiction Story Information in Elementary School Students. Budapest International Research and Critics in Linguistics and Education (BirLE) Journal Vol 3 (2): 1200-1208.

Siregar, R.G. Untung, M., and Gafari, M.O.F. (2019). The Effectiveness of Adobe Flash CS5 Learning Media on Explanatory Text Material in Public Senior High School 1 Padang Bolak. Budapest International Research and Critics in Linguistics and Education (BirLE) Journal Vol 2 (4): 470-479.

Sitompul, J. (2020). Student Perceptions of the Use of Android-Based Learning Media in the Production Ecrite Intermediaire Course. Budapest International Research and Critics in Linguistics and Education (BirLE) Journal Vol 3 (1): 616-624.

Sitorus, H.V., Nugrahadi, E.W., Budiarta, K. (2019). The Effect of Learning Strategy and Thinking Ability on ThebStudents' Learning Outcomes in Economics Subject of XI Social Students in Senior High School State 1 in Pematang Siantar. Budapest International Research and Critics in Linguistics and Education (BirLE) Journal Vol 2 (4): 451-460.

Sitorus, L.S., Mardianto, Matsum, H. (2020). Development of Powerpoint-Based Learning Media on Learning Aqeedah Morals. Budapest International Research and Critics in Linguistics and Education (BirLE) Journal Vol 3 (2): 958-964.

Syakur, A., Fanani, Z., amd Ahmadi, R. (2020). The Effectiveness of Reading English Learning Process Based on Blended Learning through "Absyak" Website Media in Higher Education. Budapest International Research and Critics in Linguistics and Education (BirLE) Journal Vol 3, (2): 763-772.

Triharso, Agung. 2013. Permainan Kreatif dan Edukatif untuk Anak. Yogyakarta: Andi.

Wahid, R., Pribadi, F., and Wakas, B.E. (2020). Digital Activism: Covid-19 Effects in Campus Learning. Budapest International Research and Critics in Linguistics and Education (BirLE) Journal Vol 3 (3): 1336-1342. 